\title{
Desulfobulbus japonicus sp. nov., a novel Gram-negative propionate-oxidizing, sulfate-reducing bacterium isolated from an estuarine sediment in Japan
}

\author{
Daisuke Suzuki, Atsuko Ueki, Aya Amaishi† and Katsuji Ueki \\ Faculty of Agriculture, Yamagata University, Wakaba-machi 1-23, Tsuruoka, Yamagata \\ 997-8555, Japan
}

Correspondence

Atsuko Ueki

uatsuko@tds1.tr.yamagata-u.ac.jp
Two strictly anaerobic, mesophilic, sulfate-reducing bacterial strains, $\operatorname{Pro}^{\top}$ and Pro16, were isolated from an estuarine sediment in the Sea of Japan of the Japanese islands and were characterized by phenotypic and phylogenetic methods. Strains Pro1 ${ }^{\top}$ and Pro16 had almost the same physiological and chemotaxonomic characteristics. Cells of both strains were Gram-negative, motile, non-spore-forming rods. Catalase activity was not detected. The optimum $\mathrm{NaCl}$ concentration for growth was $3.0 \%(\mathrm{w} / \mathrm{v})$. The optimum temperature for growth was $35^{\circ} \mathrm{C}$ and the optimum $\mathrm{pH}$ was 6.7. Both strains used formate, propionate, pyruvate, lactate, fumarate, malate, ethanol, propanol, butanol, glycerol, alanine, glucose, fructose and $\mathrm{H}_{2}$ as electron donors for sulfate reduction and did not use acetate, butyrate, succinate, methanol, glycine, serine, aspartate, glutamate, cellobiose or sucrose. Organic electron donors were incompletely oxidized mainly to acetate. Both strains also used thiosulfate as an electron acceptor. Without electron acceptors, both strains fermented pyruvate and lactate. The genomic DNA G $+C$ contents of strains Pro $1^{\top}$ and Pro16 were 48.6 and $46.0 \mathrm{~mol} \%$, respectively. The major respiratory quinone of both strains was menaquinone MK-5 $\left(\mathrm{H}_{2}\right)$. Major cellular fatty acids of both strains were $\mathrm{C}_{15: 0}, \mathrm{C}_{16: 0,}, \mathrm{C}_{17: 1} \omega 6$ and $\mathrm{C}_{18: 1} \omega 7$. Phylogenetic analysis based on $16 \mathrm{~S}$ rRNA gene sequences placed both strains in the class Deltaproteobacteria. The closest recognized relative of strains Pro ${ }^{\top}$ and Pro16 was Desulfobulbus mediterraneus with sequence similarities of 95.2 and $94.8 \%$, respectively. Based on phylogenetic, physiological and chemotaxonomic characteristics, strains Pro $^{\top}$ and Pro16 represent a novel species of the genus Desulfobulbus, for which the name Desulfobulbus japonicus is proposed. The type strain is $\operatorname{Pro1}^{\top}\left(=\mathrm{JCM} 14043^{\top}=\mathrm{DSM} 18378^{\mathrm{T}}\right)$ and strain Pro16 $(=\mathrm{JCM} 14044=\mathrm{DSM} 18379)$ is a reference strain.
Sulfate-reducing bacteria (SRB) include phylogenetically diverse anaerobic bacterial species and most of the recognized species of SRB belong to the class Deltaproteobacteria and the family Peptococcaceae in the phylum Firmicutes (Castro et al., 2000). Major intermediates of anaerobic decomposition of organic matter such as acetate, propionate, butyrate and $\mathrm{H}_{2}$ serve as the most important electron donors for sulfate-reduction in environments and thus SRB contribute significantly to the mineralization of organic matter as well as to the Earth's sulfur cycle (Jørgensen, 1982;

tPresent address: Taisei Corporation, Naze-machi 344-1, Totsuka-ku, Yokohama, Kanagawa 245-0051, Japan.

Abbreviations: CFA, whole-cell fatty acids; SRB, sulfate-reducing bacteria.

The GenBank/EMBL/DDBJ accession numbers for the 16S rRNA gene sequences of strains $\operatorname{Pro}^{\top}$ and Pro16 are $A B 110549$ and AB110550, respectively.
Sørensen et al., 1981). It is known that SRB often take a principal role in the oxidation of propionate in various anoxic environments (Parkes et al., 1993; Ueki et al., 1986). Of the propionate-oxidizing SRB from marine environments, species in the genera Desulfobacterium, Desulfonema and Desulfacinum oxidize propionate completely to carbon dioxide, whereas species in the genera Desulfobulbus, Desulforhopalus and Desulfofaba oxidize it incompletely to acetate (Kuever et al., 2005). In this study, two strains of propionate-oxidizing SRB, Prol ${ }^{\mathrm{T}}$ and Pro16, that were isolated through enrichment culture with propionate as an electron donor from an estuarine sediment from the Japanese islands (Suzuki et al., 2007) were subjected to a comprehensive characterization.

Sediment cores were collected to a depth of $6 \mathrm{~cm}$ with a core sampler (5 $\mathrm{cm}$ in diameter) from sediment at a water depth of $2 \mathrm{~m}$ in the Niida river estuary in Sakata harbour, which is 
located on the coast of the Sea of Japan in the Japanese islands $\left(38^{\circ} 54.5^{\prime} \mathrm{N} 139^{\circ} 50.6^{\prime} \mathrm{E}\right)$ on the 24 June 1999. Diluted $\left(10^{-3}-10^{-6}\right)$ sediment samples $(0.2 \mathrm{ml})$ were inoculated into liquid seawater medium containing $20 \mathrm{mM}$ of sodium propionate as described below. Cultures showing sulfate-reduction by formation of a black precipitate in the medium were transferred to fresh medium containing the same electron donor. After two to four subcultures performed in the same manner, SRB were isolated from the enrichment culture using the anaerobic roll-tube method (Hungate, 1966) with sodium propionate as an electron donor. Several strains of SRB were obtained by picking up black colonies of SRB that appeared in agar roll-tubes after about one month of incubation. Strains Pro ${ }^{\mathrm{T}}$ and Prol6 were finally obtained after several purification procedures through colony isolation by the anaerobic roll-tube method.

Two basal media (seawater medium and defined medium) were used in this study as described previously (Suzuki et al., 2007). The seawater medium, which was used for enrichment culture, contained $\left(1^{-1}\right.$ of seawater): $0.5 \mathrm{~g} \mathrm{KH}_{2} \mathrm{PO}_{4}$, $0.3 \mathrm{~g} \mathrm{NH}_{4} \mathrm{Cl}, 0.1 \mathrm{~g}$ yeast extract, $1 \mathrm{mg}$ sodium resazurin, $10 \mathrm{ml}$ trace element solution (modified from SL-10, described by Widdel et al., 1983), $1 \mathrm{ml}$ B-vitamin solution (Widdel \& Bak, 1992) and 0.5 g L-cysteine. $\mathrm{HCl}_{\text {. }} \mathrm{H}_{2} \mathrm{O}$, as well as an appropriate electron donor. The $\mathrm{pH}$ was adjusted to 7.2-7.4 with $1 \mathrm{M} \mathrm{NaOH}$. Agar (1.5\%, w/v; Difco) was added to the medium and used for the anaerobic roll-tube method for isolation and slant cultures with sodium propionate as an electron donor. The following medium, which was designated 'defined medium' in contrast to the seawater medium and used for the general physiological characterization of the strains, contained $\left(\mathrm{l}^{-1}\right): 0.5 \mathrm{~g} \mathrm{KH}_{2} \mathrm{PO}_{4}, 1.0 \mathrm{~g}$ $\mathrm{NH}_{4} \mathrm{Cl}, \quad 1.0 \mathrm{~g} \quad \mathrm{Na}_{2} \mathrm{SO}_{4}, \quad 2.0 \mathrm{~g} \quad \mathrm{MgSO}_{4} .7 \mathrm{H}_{2} \mathrm{O}, \quad 0.1 \mathrm{~g}$ $\mathrm{CaCl}_{2} .2 \mathrm{H}_{2} \mathrm{O}, 0.5 \mathrm{~g}$ yeast extract, $1 \mathrm{mg}$ sodium resazurin, $10 \mathrm{ml}$ trace element solution, $1 \mathrm{ml} \mathrm{B}$-vitamin solution, $30 \mathrm{~g}$ $\mathrm{NaCl}$ and $0.5 \mathrm{~g}$ L-cysteine. $\mathrm{HCl} . \mathrm{H}_{2} \mathrm{O}$ (Nakamoto et al., 1996; Ueki et al., 1980; Widdel \& Bak, 1992). The $\mathrm{pH}$ was adjusted to 7.2-7.4 with $1 \mathrm{M} \mathrm{NaOH}$. Agar (Difco) $(1.5 \%$, w/v) was added to the medium and used for the slant cultures with propionate as an electron donor. The concentration of sulfate in the defined medium was about $15 \mathrm{mM}$. Cultivation and transfer of the strains were performed under an $\mathrm{O}_{2}$-free $\mathrm{N}_{2}(100 \%)$ atmosphere. The strains were cultivated at $30^{\circ} \mathrm{C}$, unless stated otherwise. The strains were maintained in slant cultures of seawater medium or defined medium with sodium propionate $(20 \mathrm{mM})$ as an electron donor.

Flagella-staining was carried out according to Blenden \& Goldberg (1965). Aerobic growth was examined in the presence of sodium propionate as an electron donor using the defined medium without L-cysteine. $\mathrm{HCl}_{2} \mathrm{H}_{2} \mathrm{O}$ and sodium resazurin. Catalase and oxidase activities of cells were tested as described by Akasaka et al. (2003a). The effects of $\mathrm{NaCl}$ concentration, temperature and $\mathrm{pH}$ on growth of the strains were examined in the presence of sodium propionate as an electron donor using the defined medium. Growth of the strains was monitored by measurement of $\mathrm{OD}_{660}$ with a spectrophotometer (U1000; Hitachi).

Utilization of electron donors by the strains was determined using the defined medium containing each compound at a final concentration of $20 \mathrm{mM}$ (fatty acids, amino acids and alcohols) or $10 \mathrm{mM}$ (carbohydrates). $\mathrm{H}_{2}$ utilization was determined in the presence of sodium acetate $(5 \mathrm{mM})$ with $\mathrm{H}_{2}$ in the atmosphere. Utilization of electron acceptors was determined with sodium propionate $(20 \mathrm{mM})$ as an electron donor in a sulfate-free medium which contained the same concentrations of chloride in place of sulfate in the defined medium. Sodium sulfite $(3 \mathrm{mM})$, sodium thiosulfate or disodium fumarate $(20 \mathrm{mM}$ each) were added to the sulfate-free medium as possible electron acceptors. Utilization of pyruvate, lactate, fumarate, malate $(20 \mathrm{mM}$ each), glucose and fructose (10 $\mathrm{mM}$ each) in the absence of electron acceptors in the medium was also determined using the sulfate-free medium. Fatty acids and amino acids were used in the form of sodium salts and added to the medium from sterilized stock solutions. Utilization of each electron donor or acceptor was determined by comparing the growth $\left(\mathrm{OD}_{660}\right)$ in the presence or absence of each compound as well as by measurement of the concentration in the medium after cultivation.

Volatile fatty acids and alcohols were analysed by GC (G5000 or 263-30; Hitachi), as described by Ueki et al. (1986). Non-volatile fatty acids and formate were analysed by HPLC (LC-10AD; Shimadzu) as described by Akasaka et al. (2003a). Reducing sugars were quantified by the 3,5dinitrosalicylic acid (DNS) method (Miller, 1959). Sulfate, sulfite and thiosulfate were analysed with an ion chromatograph (2000i; Dionex) as described by Nakamoto et al. (1996). Genomic DNA was extracted according to the method described by Kamagata \& Mikami (1991). Extracted DNA was digested with P1 nuclease by using a Yamasa GC kit (Yamasa shoyu) and the $\mathrm{G}+\mathrm{C}$ content was measured by HPLC (L-7400; Hitachi) equipped with a $\mu$ Bondpack C18 column $(3.9 \times 300 \mathrm{~mm}$; Waters). Isoprenoid quinones were extracted as described by Komagata \& Suzuki (1987) and analysed by using a mass spectrometer (JMS-SX102A; JEOL). Whole-cell fatty acids (CFAs) were converted to methyl esters by saponification, methylation and extraction according to the method of Miller (1982). Methyl esters of CFAs were analysed by GC (HP6890, Hewlett Packard or G3000, Hitachi) equipped with a HP Ultra2 column. CFAs were identified by equivalent chain-length (Miyagawa et al., 1979; Ueki \& Suto, 1979) according to the protocol of TechnoSuruga Co., Ltd., based on the MIDI microbial identification system (Microbial ID) of Moore et al. (1994).

Extraction of DNA and PCR-amplification of the $16 \mathrm{~S}$ rRNA gene of the novel strains were carried out according to the method described by Akasaka et al. (2003a, b) using a primer set, $27 \mathrm{f}$ and $1492 \mathrm{r}$. The PCR-amplified $16 \mathrm{~S}$ rRNA gene was sequenced by using a Thermo Sequenase Primer Cycle 
sequencing kit (Amersham Biosciences) and a DNA sequencer (4000L; Li-COR). Multiple alignments of the sequence with reference sequences in GenBank were performed with the BLAST program (Altschul et al., 1997). A phylogenetic tree was constructed with the neighbourjoining method (Saitou \& Nei, 1987) by using the CLUSTAL W program (Thompson et al., 1994) as well as the maximumlikelihood program (DnaML) of the PHYLIP 3.66 package (Felsenstein, 2006). All gaps and unidentified base positions in the alignments were excluded before assemblages.

Strains Pro $1^{\mathrm{T}}$ and Pro16 had almost the same physiological and chemotaxonomic characteristics. Cells of both strains were Gram-negative rods with rounded ends, $0.8-1.6 \mu \mathrm{m}$ wide and 1.4-2.9 $\mu \mathrm{m}$ long. Cells usually occurred singly or in pairs (Fig. 1). Spore formation was not observed. Cells were motile by a single polar flagellum. Both strains made greyish and thin colonies on agar slants of the defined medium as well as the seawater medium.

Both strains reduced sulfate with propionate as an electron donor and produced acetate at a molar ratio of about $4: 3: 4$ (propionate: sulfate: acetate) in the defined medium, which was almost consistent with the theoretical ratio. Thus, both strains had an incomplete type of oxidation of electron donors. Growth rates of the strains were not affected by the presence or absence of the B-vitamin mixture in the defined medium containing yeast extract. Neither strain grew aerobically in the defined liquid medium. Catalase and oxidase activities were not detected. The $\mathrm{NaCl}$ concentration range for growth was $1.0-7.0 \%(\mathrm{w} / \mathrm{v})$, with an optimum at $3.0 \%(\mathrm{w} / \mathrm{v})$. The temperature range for growth was $15-35^{\circ} \mathrm{C}$, with an optimum at $35^{\circ} \mathrm{C}$. The $\mathrm{pH}$ range for growth was 6.1-7.5, with an optimum at $\mathrm{pH}$ 6.7. Both strains utilized formate, pyruvate, lactate, fumarate, malate, ethanol, propanol, butanol, glycerol, alanine, glucose,

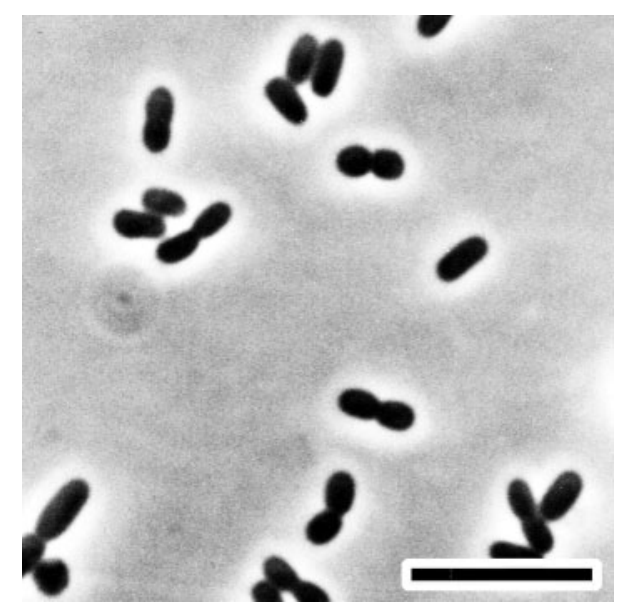

Fig. 1. A phase-contrast photomicrograph of cells of strain Pro1 $^{\top}$ grown anaerobically on an agar slant of the seawater medium. Bar, $10 \mu \mathrm{m}$. fructose and $\mathrm{H}_{2}$ as well as propionate as electron donors for sulfate reduction. Both strains grew slightly faster with pyruvate or lactate ( $\mu \approx 0.16 \mathrm{~h}^{-1}$ for both substrates) than with propionate $\left(\mu \approx 0.13 \mathrm{~h}^{-1}\right)$ as an electron donor. Although growth rates with glucose $\left(\mu \approx 0.02 \mathrm{~h}^{-1}\right)$ and fructose $\left(\mu \approx 0.07 \mathrm{~h}^{-1}\right)$ were significantly lower than that found with propionate, final growth yields with these carbohydrates reached about twice $\left(\mathrm{OD}_{660} \approx 2.0\right)$ those with propionate $\left(\mathrm{OD}_{660}=0.8-1.0\right)$. Although almost all organic electron donors were oxidized to mainly acetate, propanol and butanol were oxidized to their corresponding carboxylic acids. Propionate (about $20 \mathrm{mM}$ ) produced by oxidation of propanol $(20 \mathrm{mM})$ was not further oxidized in spite of the presence of unreduced sulfate (about $5 \mathrm{mM}$ ) in the medium. Glucose and fructose were oxidized to acetate with molar ratios of about $1: 1: 1.6-1.7$ (carbohydrates: sulfate:acetate), which were slightly different from the theoretical ratio $(1: 1: 2)$. The novel strains did not utilize acetate, butyrate, succinate, methanol, glycine, serine, aspartate, glutamate, cellobiose or sucrose as electron donors. Strain Pro $1^{\mathrm{T}}$ did not use arabinose, ribose, xylose, galactose, mannose, rhamnose, sorbose, lactose or melibiose (utilization of these compounds was not determined for strain Pro16). Strains Pro $1^{\mathrm{T}}$ and Pro16 utilized thiosulfate in addition to sulfate as an electron acceptor with propionate as an electron donor. Neither strain used sulfite or fumarate as electron acceptors. In the absence of electron acceptors, both strains oxidized pyruvate and lactate (about $5.5 \mathrm{mM}$ each) and produced acetate $(2.6-3.3 \mathrm{mM}$ ) and propionate (1.2-3.7 mM), while neither oxidized fumarate or malate. In the absence of electron acceptors, strain Prol ${ }^{\mathrm{T}}$ oxidized small amounts of glucose and fructose (about $2 \mathrm{mM}$ each) and produced trace amounts of acetate $(0.2 \mathrm{mM}$ and $0.5 \mathrm{mM}$, respectively), propionate $\left(0.2 \mathrm{mM}\right.$ each) and $\mathrm{H}_{2}$.

The $\mathrm{G}+\mathrm{C}$ contents of the genomic DNA of strains Pro1 ${ }^{\mathrm{T}}$ and Prol6 were 48.6 and $46.0 \mathrm{~mol} \%$, respectively. The major respiratory quinone of both strains was menaquinone MK-5 $\left(\mathrm{H}_{2}\right)$. Strains Pro1 ${ }^{\mathrm{T}}$ and Pro16 had almost the same content of CFAs with $\mathrm{C}_{15: 0}$ (21.0 and $21.7 \%$, respectively), $\mathrm{C}_{16: 0}(7.5$ and $7.1 \%), \mathrm{C}_{17: 1} \omega 6(39.2$ and $46.4 \%)$ and $\mathrm{C}_{18: 1} \omega 7$ (12.4 and $\left.11.4 \%\right)$ as major CFAs for both strains.

Almost full-length 16S rRNA gene sequences were determined for both strains (Pro1 ${ }^{\mathrm{T}}, 1485 \mathrm{bp}$; Pro16, $1479 \mathrm{bp}$ ). The sequence similarity between the two strains was $98.1 \%$. Based on phylogenetic analysis of the $16 \mathrm{~S}$ rRNA gene sequence, strains Prol ${ }^{\mathrm{T}}$ and Prol6 were affiliated with the class Deltaproteobacteria and formed a cluster in the family Desulfobulbaceae (Fig. 2). The closest relative of both strains found on the database was Desulfobulbus sp. BG25, isolated from salt marsh sediment, with gene sequence similarities of 98.5 and $98.4 \%$ to strains $\operatorname{Prol}^{\mathrm{T}}$ and Pro16, respectively. The closest recognized species to the novel strains were Desulfobulbus mediterraneus (Sass et al., 2002), with sequence similarities of 95.2 (sequence length compared, $1428 \mathrm{bp}$ ) and $94.8 \%$ (1429 bp), respectively, and Desulfobulbus rhabdoformis (Lien et al., 1998) with sequence 


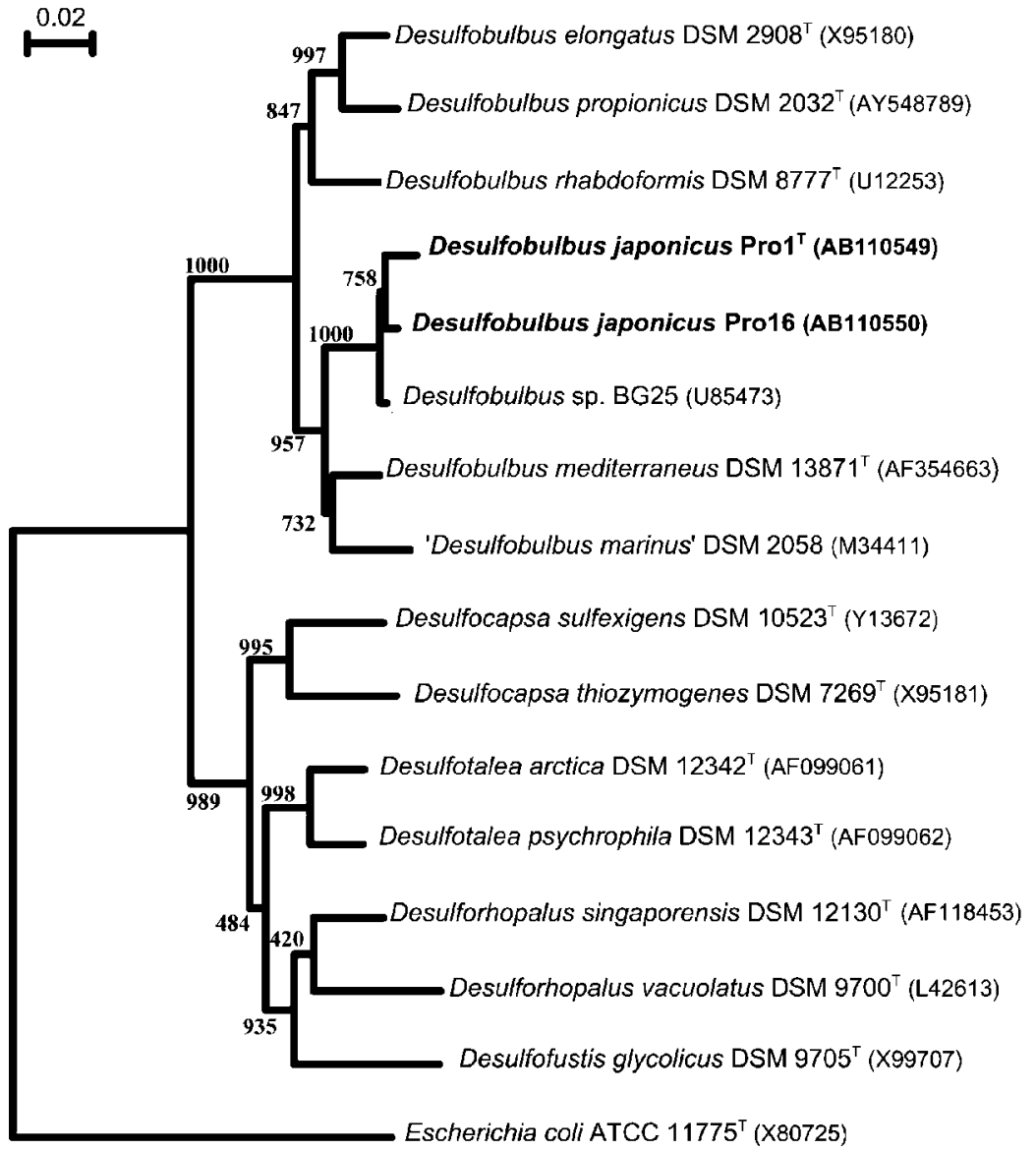

Fig. 2. Neighbour-joining tree showing the phylogenetic relationship of strains $\operatorname{Pro}^{\top}$ and Pro16 and related species in the class Deltaproteobacteria based on 16S rRNA gene sequences. Bootstrap values shown are based on analysis of 1000 replicates. Escherichia coli was used as the outgroup. Tree topology evaluated by the maximumlikelihood method was almost the same as that obtained with the neighbour-joining method. Bar, estimated difference of $2 \%$ in nucleotide sequence positions. similarities of 94.0 (1453 bp) and $93.7 \%$ (1457 bp), respectively. Sequence similarities with 'Desulfobulbus marinus' (Widdel \& Pfennig, 1982) were 94.1 and $94.5 \%$, respectively, although the sequence length available for comparison was rather short (1211 bp).

Physiological and chemotaxonomic characteristics of both strains were compared with those of all described species in the genus Desulfobulbus (Table 1). The incomplete oxidation of propionate as an electron donor for sulfatereduction and production of acetate and propionate from lactate and pyruvate without electron acceptors are both specific characteristics for Desulfobulbus species. Thus, strains $\operatorname{Prol}^{\mathrm{T}}$ and Prol6 share several important features with species of the genus Desulfobulbus, including cell morphology and the composition of major respiratory quinone.

The ranges of electron donors utilized by strains $\operatorname{Prol}^{\mathrm{T}}$ and Pro16 were not consistent with any of the recognized species of the genus Desulfobulbus, especially for the electron donors such as formate, fumarate, malate, succinate, glycerol, alanine and glutamate (Table 1). Strains Pro $1^{\mathrm{T}}$ and Pro16 are the second group in the genus Desulfobulbus that have been reported to utilize carbohydrates as electron donors for sulfate reduction, although the range of carbohydrates utilized is rather limited compared with that of $D$. mediterraneus (Sass et al., 2002). D. mediterraneus is reported to ferment glucose and fructose in the absence of electron acceptors, whereas strain $\operatorname{Prol}^{\mathrm{T}}$ only slightly consumed them and grew very weakly on them.

As shown in Table 1, the DNA G+C contents of Desulfobulbus species seem to be divided into two levels (47-50\% and about 59\%, respectively). The DNA G + C contents of strains Pro $1^{\mathrm{T}}$ and Pro16 were almost consistent with those of the lower level. The CFA profiles of the novel strains are compared with those of the closest relatives, $D$. mediterraneus and D. rhabdoformis, in Table 2. Strains Pro $^{\mathrm{T}}$ and Pro16 shared a common profile of overall CFA composition with these phylogenetic relatives. Although differences in the cultivation conditions of cells should be considered when comparing CFA profiles, major differences between the species were found for CFAs such as $\mathrm{C}_{14: 0}$, $\mathrm{C}_{15: 0}, \mathrm{C}_{16: 1} \omega 7, \mathrm{C}_{17: 1} \omega 6$ and $\mathrm{C}_{18: 1} \omega 7$.

Based on the phylogenetic, physiological and chemotaxonomic characteristics described above, strains $\operatorname{Pro}^{\mathrm{T}}$ and Pro16 should be classified as members of the genus Desulfobulbus and we propose that they represent a novel species, Desulfobulbus japonicus sp. nov., with strain $\operatorname{Prol}^{\mathrm{T}}$ as the type strain. 
Table 1. Some characteristics of strains $\operatorname{Pro1}^{\top}$, Pro16 and other Desulfobulbus species

Strains: 1, Pro1 ${ }^{\mathrm{T}}$; 2, Pro16; 3, Desulfobulbus mediterraneus 86FS1 ${ }^{\mathrm{T}}$ (Sass et al., 2002); 4, Desulfobulbus rhabdoformis M16 ${ }^{\mathrm{T}}$ (Lien et al., 1998; Kuever et al., 2005); 5, 'Desulfobulbus marinus' 3 pr10 (Widdel \& Pfennig, 1982; Kuever et al., 2005); 6, Desulfobulbus elongatus FP ${ }^{\mathrm{T}}$ (Samain et al., 1984); 7, Desulfobulbus propionicus $1 \mathrm{pr}^{\mathrm{T}}$ (Widdel \& Pfennig, 1982). +, Used; W, weakly used; -, not used; ND, not determined or no data available.

\begin{tabular}{|c|c|c|c|c|c|c|c|}
\hline Characteristic & 1 & 2 & 3 & 4 & 5 & 6 & 7 \\
\hline Cell shape & Rods & Rods & Ovoid & Rods & Oval & Rods & Oval or lemon \\
\hline Motility & Motile & Motile & Motile & Non-motile & Motile & Motile & Non-motile \\
\hline Temperature $\left({ }^{\circ} \mathrm{C}\right)$ & 35 & 35 & 25 & 31 & 29 & 31 & 39 \\
\hline $\mathrm{pH}$ & 6.7 & 6.7 & $\mathrm{ND} \dagger$ & $6.8-7.2$ & 7.4 & 7.0 & $7.1-7.5$ \\
\hline \multicolumn{8}{|l|}{ Utilization of electron donors: } \\
\hline Alanine & + & + & + & ND & $\mathrm{ND}$ & $\mathrm{ND}$ & - \\
\hline Cellobiose & - & - & + & ND & $\mathrm{ND}$ & $\mathrm{ND}$ & - \\
\hline Glucose & + & + & + & $\mathrm{ND}$ & $\mathrm{ND}$ & - & - \\
\hline Glutamate & - & - & + & $\mathrm{ND}$ & $\mathrm{ND}$ & $\mathrm{ND}$ & $\mathrm{ND}$ \\
\hline Glycerol & + & + & - & $\mathrm{ND}$ & $\mathrm{ND}$ & $\mathrm{ND}$ & $\mathrm{ND}$ \\
\hline $\mathrm{H}_{2}$ & + & + & - & + & + & + & + \\
\hline Lactose & - & $\mathrm{ND}$ & + & $\mathrm{ND}$ & $\mathrm{ND}$ & ND & $\mathrm{ND}$ \\
\hline Malate & + & + & + & + & - & - & - \\
\hline Ribose & - & $\mathrm{ND}$ & + & $\mathrm{ND}$ & $\mathrm{ND}$ & $\mathrm{ND}$ & ND \\
\hline Succinate & - & - & + & + & - & - & - \\
\hline Sucrose & - & - & + & ND & $\mathrm{ND}$ & ND & ND \\
\hline \multicolumn{8}{|c|}{ Utilization of electron acceptors: } \\
\hline Sulfite & - & - & + & + & + & + & + \\
\hline Isoprenoid quinone & $\mathrm{MK}-5\left(\mathrm{H}_{2}\right)$ & $\mathrm{MK}-5\left(\mathrm{H}_{2}\right)$ & ND & $\mathrm{MK}-5\left(\mathrm{H}_{2}\right)$ & $\operatorname{MK}-5\left(\mathrm{H}_{2}\right)$ & $\operatorname{MK}-5\left(\mathrm{H}_{2}\right)$ & $\operatorname{MK}-5\left(\mathrm{H}_{2}\right)$ \\
\hline
\end{tabular}

${ }^{*}$ Strains $\mathrm{FP}^{\mathrm{T}}$ and $1 \mathrm{pr} 3^{\mathrm{T}}$ do not require $\mathrm{NaCl}$ for growth.

$\dagger$ Strain $86 \mathrm{FS}^{\mathrm{T}}$ does not grow at $\mathrm{pH}$ values below 6.3 and above 8.0.

Description of Desulfobulbus japonicus sp. nov.

Desulfobulbus japonicus (ja.po'ni.cus. N.L. masc. adj. japonicus pertaining to Japan, from where the type strain was originally isolated).

Cells are rod-shaped, 0.8-1.6 $\mu \mathrm{m}$ wide and 1.4-2.9 $\mu \mathrm{m}$ long. Strictly anaerobic. Gram-negative. Motile by a single polar flagellum. Non-spore-forming. Catalase and oxidase activities are not detected. Colonies are greyish and thin and spread on slant media. The $\mathrm{NaCl}$ concentration range for growth is $1.0-7.0(\mathrm{w} / \mathrm{v})$, with an optimum at $3.0 \%(\mathrm{w} / \mathrm{v})$. The temperature range for growth is $15-35^{\circ} \mathrm{C}$, with an optimum at $35^{\circ} \mathrm{C}$. The $\mathrm{pH}$ range for growth is $6.1-7.5$, with an optimum at $\mathrm{pH}$ 6.7. Utilizes formate, propionate, pyruvate, lactate, fumarate, malate, ethanol, propanol, butanol, glycerol, alanine, glucose, fructose and $\mathrm{H}_{2}$ as electron donors for sulfate reduction. Does not use acetate, butyrate, succinate, methanol, glycine, serine, aspartate, glutamate, arabinose, ribose, xylose, galactose, mannose, rhamnose, sorbose, cellobiose, lactose, melibiose or sucrose. 
Table 2. Cellular fatty acid contents (\%) of strains $\operatorname{Pro}^{\top}$, Pro16 and related species

Strains: $1, \operatorname{Prol}^{\mathrm{T}}$; 2, Pro16; 3, Desulfobulbus mediterraneus $86 \mathrm{FS1}^{\mathrm{T}}$ (Sass et al., 2002); 4, Desulfobulbus rhabdoformis $\mathrm{M} 16^{\mathrm{T}}$ (Lien et al., 1998). -, Not detected. The following temperatures were used for cultivation: Prol ${ }^{\mathrm{T}}$, Pro 16 and $\mathrm{M} 16^{\mathrm{T}}, 30^{\circ} \mathrm{C} ; 86 \mathrm{FS}^{\mathrm{T}}, 20^{\circ} \mathrm{C}$.

\begin{tabular}{|lcccc|}
\hline Fatty acid & $\mathbf{1}$ & $\mathbf{2}$ & $\mathbf{3}$ & $\mathbf{4}$ \\
\hline Saturated straight-chain: & & & & \\
$\mathrm{C}_{11: 0}$ & - & 2.3 & - & - \\
$\mathrm{C}_{14: 0}$ & 2.7 & - & 11.4 & 9.4 \\
$\mathrm{C}_{15: 0}$ & 21.0 & 21.7 & 1.9 & 13.9 \\
$\mathrm{C}_{16: 0}$ & 7.5 & 7.1 & 3.0 & - \\
$\mathrm{C}_{17: 0}$ & 2.1 & 3.1 & - & - \\
$\mathrm{C}_{18: 0}$ & 1.0 & - & - & - \\
Unsaturated straight-chain: & & & & \\
$\mathrm{C}_{14: 1} \omega 5$ & - & - & 0.5 & - \\
$\mathrm{C}_{15: 1} \omega 8$ & - & - & 0.9 & - \\
$\mathrm{C}_{15: 1} \omega 6$ & 1.4 & - & 2.4 & - \\
$\mathrm{C}_{16: 1} \omega 7$ & 3.0 & 3.5 & 27.1 & 7.9 \\
$\mathrm{C}_{16: 1} \omega 5$ & 2.3 & 2.1 & 9.9 & 4.4 \\
$\mathrm{C}_{17: 1} \omega 8$ & 1.9 & - & 1.1 & - \\
$\mathrm{C}_{17: 1} \omega 6$ & 39.2 & 46.4 & 11.1 & 24.1 \\
$\mathrm{C}_{18: 1} \omega 7$ & 12.4 & 11.4 & 26.6 & 24.5 \\
Unsaturated branched-chain: & & & & \\
Branched $_{17: 1}$ & 2.6 & 2.4 & - & - \\
\hline
\end{tabular}

Almost all organic electron donors are incompletely oxidized to acetate. Sulfate and thiosulfate serve as electron acceptors. Does not use sulfite or fumarate. Pyruvate and lactate are fermented in the absence of electron acceptors to acetate and propionate. The genomic DNA G $+\mathrm{C}$ content is 46.0-48.6 mol\%. Major cellular fatty acids are $\mathrm{C}_{15: 0}, \mathrm{C}_{16: 0}$, $\mathrm{C}_{17: 1} \omega 6$ and $\mathrm{C}_{18: 1} \omega 7$. The major respiratory quinone is menaquinone $\mathrm{MK}-5\left(\mathrm{H}_{2}\right)$.

The type strain, $\operatorname{Prol}^{\mathrm{T}}\left(=\mathrm{JCM} 14043^{\mathrm{T}}=\operatorname{DSM} 18378^{\mathrm{T}}\right)$, was isolated from an estuarine sediment located on the side of the Sea of Japan of the Japanese islands. Strain Pro16 $(=$ JCM $14044=$ DSM 18379) is a reference strain.

\section{Acknowledgements}

We are grateful to Professor Tetsuya Murayama and Professor Kouetsu Takahashi for their technical instruction on the determination of isoprenoid quinones for the strains. This work was partly supported by a Grant-in-Aid from the Institute for Fermentation, Osaka.

\section{References}

Akasaka, H., Izawa, T., Ueki, K. \& Ueki, A. (2003a). Phylogeny of numerically abundant culturable anaerobic bacteria associated with degradation of rice plant residue in Japanese paddy field soil. FEMS Microbiol Ecol 43, 149-161.
Akasaka, H., Ueki, A., Hanada, S., Kamagata, Y. \& Ueki, K. (2003b). Propionicimonas paludicola gen. nov., sp. nov., a novel facultatively anaerobic, Gram-positive, propionate-producing bacterium isolated from plant residue in irrigated rice-field soil. Int J Syst Evol Microbiol 53, 1991-1998.

Altschul, S. F., Madden, T. L., Schäffer, A. A., Zhang, J., Zhang, Z., Miller, W. \& Lipman, D. J. (1997). Gapped BLAST and PSI-BLAST: a new generation of protein database search programs. Nucleic Acids Res 25, 3389-3402.

Blenden, D. C. \& Goldberg, H. S. (1965). Silver impregnation stain for Leptospira and flagella. J Bacteriol 89, 899-900.

Castro, H. F., Williams, N. H. \& Ogram, A. (2000). Phylogeny of sulfate-reducing bacteria. FEMS Microbiol Ecol 31, 1-9.

Felsenstein, J. (2006). PHYLIP (Phylogeny Inference Package), v3.66. Department of Genome Sciences, University of Washington, Seattle.

Hungate, R. E. (1966). The Rumen and its Microbes. New York: Academic Press.

Jørgensen, B. B. (1982). Mineralization of organic matter in the sea bed - the role of sulphate reduction. Nature 296, 643-645.

Kamagata, Y. \& Mikami, E. (1991). Isolation and characterization of a novel thermophilic Methanosaeta strain. Int J Syst Bacteriol 41, 191-196.

Komagata, K. \& Suzuki, K. (1987). Lipid and cell-wall analysis in bacterial systematics. Methods Microbiol 19, 161-207.

Kuever, J., Rainey, F. A. \& Widdel, F. (2005). Class IV. Deltaproteobacteria class nov. In Bergey's Manual of Systematic Bacteriology, Vol. 2, Part C, 2nd edn, pp. 922-1144. Edited by D. J. Brenner, N. R. Krieg, J. T. Staley \& G. M. Garrity. New York: Springer.

Lien, T., Madsen, M., Steen, I. H. \& Gjerdevik, K. (1998). Desulfobulbus rhabdoformis sp. nov., a sulfate reducer from a water-oil separation system. Int J Syst Bacteriol 48, 469-474.

Miller, G. L. (1959). Use of dinitrosalicylic acid reagent for determination of reducing sugar. Anal Chem 31, 426-428.

Miller, L. T. (1982). Single derivatization method for routine analysis of bacterial whole-cell fatty acid methyl esters, including hydroxy acids. J Clin Microbiol 16, 584-586.

Miyagawa, E., Azuma, R. \& Suto, E. (1979). Cellular fatty acid composition in Gram-negative obligately anaerobic rods. J Gen Appl Microbiol 25, 41-51.

Moore, L. V. H., Bourne, D. M. \& Moore, W. E. C. (1994). Comparative distribution and taxonomic value of cellular fatty acids in thirtythree genera of anaerobic gram-negative bacilli. Int J Syst Bacteriol 44, 338-347.

Nakamoto, M., Ueki, A. \& Ueki, K. (1996). Physiological properties of a sulfate-reducing bacterium isolated from municipal sewage sludge and its possible role as a syntrophic acidogen in the ecosystem. J Gen Appl Microbiol 42, 109-120.

Parkes, R. J., Dowling, N. J. E., White, D. C., Herbert, R. A. \& Gibson, G. R. (1993). Characterization of sulfate-reducing bacterialpopulations within marine and estuarine sediments with different rates of sulfate reduction. FEMS Microbiol Ecol 102, 235-250.

Saitou, N. \& Nei, M. (1987). The neighbor-joining method: a new method for reconstructing phylogenetic trees. Mol Biol Evol 4, 406-425.

Samain, E., Dubourguier, H. C. \& Albagnac, G. (1984). Isolation and characterization of Desulfobulbus elongatus sp. nov. from a mesophilic industrial digester. Syst Appl Microbiol 5, 391-401.

Sass, A., Rütters, H., Cypionka, H. \& Sass, H. (2002). Desulfobulbus mediterraneus sp. nov., a sulfate-reducing bacterium growing on mono- and disaccharides. Arch Microbiol 177, 468-474.

Sørensen, J., Christensen, D. \& Jørgensen, B. B. (1981). Volatile fatty acids and hydrogen as substrates for sulfate-reducing bacteria in anaerobic marine sediment. Appl Environ Microbiol 42, 5-11. 
Suzuki, D., Ueki, A., Amaishi, A. \& Ueki, K. (2007). Desulfopila aestuarii gen. nov., sp. nov., a novel, Gram-negative, rod-like sulfatereducing bacterium isolated from an estuarine sediment in Japan. Int J Syst Evol Microbiol 57, 520-526.

Thompson, J. D., Higgins, D. G. \& Gibson, T. J. (1994). CLUSTAL W: improving the sensitivity of progressive multiple sequence alignment through sequence weighting, position-specific gap penalties and weight matrix choice. Nucleic Acids Res 22, 4673-4680.

Ueki, A. \& Suto, T. (1979). Cellular fatty acid composition of sulfatereducing bacteria. J Gen Appl Microbiol 25, 185-196.

Ueki, A., Minato, H., Azuma, R. \& Suto, T. (1980). Enumeration and isolation of anaerobic bacteria in sewage digester fluids: enumeration of sulfate-reducers by the anaerobic roll tube method. J Gen Appl Microbiol 26, 25-35.
Ueki, A., Matsuda, K. \& Ohtsuki, C. (1986). Sulfate reduction in the anaerobic digestion of animal waste. J Gen Appl Microbiol 32, 111-123.

Widdel, F. \& Pfennig, N. (1982). Studies on dissimilatory sulfatereducing bacteria that decompose fatty acids. II. Incomplete oxidation of propionate by Desulfobulbus propionicus gen. nov., sp. nov. Arch Microbiol 131, 360-365.

Widdel, F. \& Bak, F. (1992). Gram-negative mesophilic sulfatereducing bacteria. In The Prokaryotes, pp. 3352-3378. Edited by A. Balows, H. G. Trüper, M. Dworkin, W. Harder \& K.-H. Schleifer. New York: Springer.

Widdel, F., Kohring, G. W. \& Mayer, F. (1983). Studies of dissimilatory sulfate-reducing bacteria that decompose fatty acids. III. Characterization of the filamentous gliding Desulfonema limicola gen. nov. and sp. nov. and Desulfonema magnum sp. nov. Arch Microbiol 134, 286-294. 